\title{
9
}

\section{THE RELIVING OF MINOR TACTICS Reflections of a platoon commander's war in Korea}

\author{
Colin Kahn
}

Former United States Chief of Army General Bruce Clarke wrote: 'The paramount concern of the Army is the ground combat soldier. It will be a sorry day for us all in this supersonic, nuclear age should the ground combat soldier ever be deprived of his rightful place in the hearts and minds of the military forces and the people.' This chapter focuses on those responsible for the tactical fighting of Australian-conducted operations in Korea: infantry rifle sections and platoons, for this was primarily an infantry soldier's war.

Although I will concentrate on the activities of rifle platoons, the infantrymen who served in Korea can never forget the contributions and support given by other arms and services, especially artillery, which frequently proved to be battle-winning contributions that led to success or survival. While it did happen, it was rare that Australian rifle platoons fought without support.

When preparing this chapter I was reminded of Montaigne's words, 'I have gathered a posy of other men's flowers, and only the string that binds them is mine'. I participated only in the static, patrol phase of the war in 1952; for the mobile and attack phases, I have relied on the flowers 
provided to me by the experienced, outstanding warrant officers and senior non-commissioned officers (NCOs) with whom I have served, and with whom I have instructed on the topic of Infantry Minor Tactics, both at the School of Infantry in Singleton, NSW, and in Canberra at Duntroon. Incidentally, most of these NCOs served in Korea with our 3rd Battalion, Royal Australian Regiment (3RAR). They never let me forget that if you did not serve in the 3rd Battalion, you did not really serve in Korea; and even then, if you were not in the first mobile phase with the 3rd Battalion, when they had the fun of going up and down the peninsula, you still did not really serve in Korea.

In Korea, indeed as ever, good platoon commanders put their individual stamp on the workings and the life of their platoon. This stamp, this mark, made on all successful platoons, included the stamp of high morale, of aggression, of example and the adaptation of tried and known minor tactics to his own platoon. As a result of this individualism, one must tend to generalise when talking of platoon activities. However, because of our training in proven minor tactics, learnt during the Second World War at platoon and company level, application was generally common; and what one subunit of the RAR did well (or, on rare occasions, not so well) would or could have been done by any other Australian subunit. This leads us into considering the building blocks in the structure and application of how we operated.

\section{The men-composition}

First among these blocks were the men who comprised our subunits. Company commanders generally had Second World War experience, as did some platoon commanders. The majority of platoon commanders were, however, recent Duntroon graduates, well trained in minor tactics and leadership, and anxious to prove themselves in battle. Hence this ingredient of minor tactics was present in Korea: uniform, tried battle experience, or highly trained, enthusiastic young officers.

The soldiers were a mixture. Some were Korea Force volunteers-men, in the main Second World War veterans, who specifically enlisted for the duration of the Korean War, something rather unique. They came not only from Australia but also from overseas, especially the United Kingdom, and many were not ex-soldiers but were ex-airmen or ex-sailors; I had two in my platoon. These men were mature and in the main battle- 
hardened to varying degrees. Next were the young regular soldiers, many 18 or 19 years old, of the recently formed Australian Regular Army. This blending of experience and youth proved to be a great success in battle.

Weapons and equipment are clearly two major determinants of minor tactics. With the end of the Second World War less than five years before, it was no surprise that we went to Korea with what was left over from the Second World War. There was nothing that was new. The basic Australian infantry weapon was the bolt-action, single-firing .303 rifle and bayonet; each section had one Bren light machine gun and M36 grenades. Meanwhile infantry section commanders and most platoon commanders had Owen submachine guns, which were used extensively in the Second World War. At times, within the platoon there was a 3.5-inch rocket launcher and a 2-inch mortar, in addition to the platoon commander having an 88 set radio for communications with his company commander; communications between sections was by voice or hand signals. It is also important to remember that all movement was by foot, by truck, by jeep or on tanks; there were no lift helicopters.

As the war progressed, and trading with the Americans increased, platoon weapons slightly changed. Major changes occurred during the static phase of the war, when platoons armed themselves with more light machine guns and submachine guns for patrolling purposes. But primarily platoon weapons remained the same as in the Second World War.

The effect that clothing had on minor operations became very clear in the freezing conditions of Korea. Initially our troops went in Second World War clothing (some of it from the Middle East) and web equipment: slouch hats, leather studded boots, web gaiters and old field dress. Gradually, platoons were more appropriately attired with British and US underclothing, smocks, fleecy caps, winter boots, gloves with firing fingers, sleeping bags and so on. Lack of suitable clothing restricted the time troops could spend out in the cold; and without suitable gloves, fingers stuck to gun metal.

The old saying 'as you train, so will you fight' stayed true. The training of soldiers and NCOs was generally sound, with many in the 3rd Battalion having trained and/or served in Japan with the British Commonwealth Occupation Force (BCOF). Reinforcements trained at home for up to six months-from 1952 onwards, they were trained by Korean veterans. 
All troops on arrival in Japan went to the British battle school in the mountains at Hara-Mura in Nagano prefecture where they were trained by veteran instructors.

While many section commanders brought Second World War experience with them, and NCO courses were run in New South Wales and Victoria, much still remained to be done under the guidance of experienced company sergeant majors and platoon sergeants, almost all of them with Second World War experience. Not all leadership training was uniform or extensive, however. A well-known retired warrant officer class 1 wrote to this author recently: 'I joined the Army at 21, in January 1950; I was in Korea by September and was immediately made a lance corporal, and within two weeks I was a corporal section commander. Most of my training and leadership skills as a section commander was on-the-job learning from old K Force veterans in my section.'

\section{Mobile phase}

An understrength 3RAR in Japan needed reinforcements and further training to get it to Pusan in September 1950, and in October the first major engagements with the North Koreans occurred at the Apple Orchard and the Broken Bridge. The mobile phase of the war for Australian troops was well underway.

These advance operations, going up the peninsula, were identified with infantry platoons mounted in trucks, on tanks or on foot, clearing advance centre lines and flanks; and when enemy positions were encountered, they mounted quick assaults, frequently with grenade and bayonet, to force the enemy to withdraw. These were classical advances to contact, identified by quick off-the-march assaults, frequently across open paddy fields at section level, and supported by artillery and US air power. Some of the terrain encountered during this advance in central North Korea included steep ridges covered in pine forests, causing platoons to revisit fighting experienced in the Second World War, up ridge lines in New Guinea. At times, advance frontages were restricted to two or three men, or less.

The advance operations went on for six months, then the units became involved in withdrawals from North Korea in the face of massive Chinese intervention. Rear guards and temporary defensive positions were established in defiles, at crossroads and bridges, to cover withdrawals of 
United Nations (UN) troops mixed in with refugees. In the many major and minor encounters during this phase, the operations of the infantry subunits were characterised by quick, aggressive action that enabled orderly withdrawal with minimum losses.

\section{Defensive battle-Kapyong}

As the major defensive Battle of Kapyong is covered elsewhere in this book (especially chapters 3 and 4), this chapter will refer briefly to the actions of platoons to indicate how the leadership and aggression shown at junior levels in the previous mobile phase was repeated by platoons in defence. Generally, 3RAR companies and platoons were in widely dispersed, unprepared defensive positions on hilltops around Kapyong valley, and were attacked by wave after wave of Chinese assaults. Forward companies were cut off, with further confusion caused by refugees and others fleeing through the area.

Being a hastily occupied defence, deep weapon pits or trenches were replaced by hastily prepared shell scrapes or protective mounds of stones. Sections relied primarily on .303 single-shot rifles, with automatic fire from one light machine gun and one submachine gun per section. More automatic weapons were needed to defeat mass assaults. The Chinese assaults-almost always preceded by whistles and bugles for communication-normally consisted of Chinese soldiers closing to grenade range, followed by charges with rifles and burp guns. ${ }^{1}$ This major defensive battle was won by resolute and aggressive defence by sections and platoons holding their positions; or, when these were lost or overrun, conducting local counter-attacks, frequently without support, but using grenade and bayonet to regain lost weapon pits.

Overall, this major battle was supported by US air, especially Corsairs dropping napalm, and by US Sherman tanks that provided fire support, brought up ammunition and evacuated casualties. On one night, however, there was no artillery or other support available to 3RAR, and the companies and platoons repelled several major night assaults, using only their own infantry weapons: rifles and light machine guns. Dead and

1 A burp gun is a Russian-made submachine gun; see 'The burp gun was ugly-but damn did it spray lead', War is Boring, 15 October 2014, medium.com/war-is-boring/the-burp-gun-was-ugly-butdamn-did-it-spray-lead-cc4730dadfe8. 
wounded from forward weapon pits were taken to rear positions and replaced by fit men from the rear. Some section strengths were reduced to fewer than four men. Eventually, companies were forced to withdraw, under pressure, by leap-frogging sections and platoons back while they covered each other. This battle was fought and won at section, platoon and company level by resolute and aggressive defence.

\section{Chinese tactics}

As explained by Xiaobing $\mathrm{Li}$ in Chapter 3, the initial tactics of the Chinese forces in 1950 involved using mass numbers - even launching daylight attacks - until losses caused by overwhelming air and artillery support caused them to revert to movement and attack primarily at night. Attack tactics were to close on UN forces as closely as possible, avoiding detection, then to charge, using grenades and burp guns, with movements frequently controlled by whistles and bugles. Preliminary stick grenade assault was standard. Some UN and Australian reports speak of enemy assault waves not having any weapons at all, but relying on picking up the weapons of Chinese soldiers killed in earlier waves.

In a conversation with a Chinese colonel who had been a staff officer with a division in Korea in 1950-51, he confirmed that there was an initial shortage of radios and that Chinese forces did use bugles to communicate and control assaults. He also pointed out that they had reverted to night attacks, but would not agree that unarmed soldiers were sent into battle. He said weapons were picked up only if they were better than the one the soldier was carrying.

Later discussions with staff colleagues at the Canadian Army Staff College, members from Princess Patricia's Canadian Light Infantry who had fought at Kapyong, echoed the platoon experiences of 3RAR.

\section{Attack battle}

Australia had only one major attack battle in Korea, which was at Maryang San: Operation Commando, which must rank as one of the most successful battalion battles fought by Australian troops. It is covered by Bob Breen in Chapter 10 of this book, so again I will provide a brief overview. 
The outstanding success of Operation Commando, putting aside the brilliance of the battalion commander's actions, was again due to the professionalism and the aggressive leadership shown by experienced company commanders - and by so many professionally trained young platoon commanders and battle-experienced warrant officers and NCOs, leading soldiers of high morale and good training. Australia subsequently took most of these same warrant officers and NCOs to Vietnam, together with a new generation of similarly professionally trained young officers and soldiers (both regulars and national servicemen) of high morale and aggression. In that war, with such men, it is no wonder we did as well as we did.

Operation Commando was the epitome of infantry minor tactics, a battle of basic fire and movement, of aggressive assault, of defence against counterattack, of aggressive leadership and determined response by troops to get what they were after. This was a classic infantry battle, fought and won at platoon level, with platoons passing through platoons to sustain pressure on the enemy and keep the momentum of the assault going, while other platoons gave covering fire. Frequently, Bren gunners would take over faltering assaults to maintain the momentum of attacks, followed by Australian troops attacking enemy positions with grenades, then charging with bayonets. This was a six-day attack battle, up ridges against an entrenched enemy, where assault frontages were at times reduced to a few men on ridge lines. Again, assaults were successful with the assistance of great artillery support. Time was always of the essence. Instant obedience to orders by all in the attack, the willingness to press on under fire, and for soldiers to assume command when section commanders were wounded, all led to success.

\section{The static war}

As other chapters have attested, in the last one and a half years of the war Korea moved from high-level tactics of divisions, brigades and battalions to a platoon-level, tactical war-or, more correctly, a patrol commanders' war. It was a war of artillery and mortar duels, of trenches and dugouts, of patrols and raids to capture prisoners, the occupation of high ground; a war of mines and barbed wire; a war in which Australian battalions would commit at least a quarter of their strength, night after 
night, to protect positions by dominating no man's land with patrols of all kinds-fighting, ambush, reconnaissance, standing, protective, listening posts - and by applying tactics learnt from the two world wars.

It became a war in which enemy artillery and mortar fire could be as intense as our own, and in which our tanks supported patrols, not by moving with us, but by firing from static positions and sniping against enemy bunkers. Enemy patrolling and reaction was frequently as aggressive and as successful as ours, and a well-armed enemy negated our air superiority by mounting major operations only at night. It remained, for us, a war led by experienced Second World War company commanders and a great proportion of four-year-trained young professional platoon commanders. The impact of this patrol war can be gauged by considering that of the 30 members of my Duntroon class who went to Korea, more than 60 per cent were killed, captured or seriously wounded during that patrol phase of the war.

The static period of the Korean War was interspersed with several operations above platoon level, including when the 1st Battalion, Royal Australian Regiment (1RAR), launched a conventional daylight company attack against the well-defended enemy Hill 227, and a night company attack on a hill behind enemy front lines near Hill 355. Both were at company level and involved classic company attacks, designed to capture prisoners; both ended without success. Heavily supported, they reached their objectives, and occupied enemy-held trenches and assaulted the enemy with bayonets and grenades. As David Horner points out in Chapter 8, during the last three days of the war, the 2nd Battalion, Royal Australian Regiment (2RAR), and US Marines fought a major defensive battle on the Hook against massed Chinese attacks.

The period of static defence during the Korean War was defined by a number of key characteristics that influenced the tactics of Australian forces. Frequently, infantry would be required to support air attacks against enemy positions by firing across the valley into enemy bunkers to prevent them firing against UN air assets. This was one of the few instances, so far as I know, when the army supported the air force. Australian forces also used tanks and riflemen to act as snipers, while search lights were critical in illuminating no man's land and assisting defensive patrols. Night sentries were normally present in every section and included at least two soldiers. Defensive locations were based on platoons and were connected to company headquarters by communication trenches. While forward, 
platoons were generally on isolated hilltops, and beyond this were small standing patrols or listening posts. These forward listening and observation posts were responsible for raising the alarm if the enemy was approaching and to count Australian patrols going out and coming back. The posts were connected to their platoon and company by land telephone line.

In the closing stages of the Korean War, some defensive positions had become complex and sophisticated. Such defensive positions had extensive overhead protection; troops could withdraw and call down friendly fire on top of their own position if the enemy were there. Mines were laid in front of defensive locations but were of mixed benefit because they rarely stopped enemy probes and tended to limit their own movementspatrols had to go out through known mine gaps, and come back the same way, which the enemy got to know. Confusion was caused by differing layouts used by the various UN units. Minefields were delineated by fences, which could be destroyed by fire or hidden by vegetation. Markers were lost. Disoriented patrols returning from a contact would wander into their own minefields, resulting in casualties. Reinforcements were not always aware of the locations of minefield gaps, but the enemy knew them all. At times minefields included drums of fuel detonated by trip wire or by explosive bullets. As in the First World War, barbed wire proved to be a formidable defensive obstacle and was often placed at the front of trenches to slow down enemy forces.

Artillery played a critical role for both sides during the Korean War. Australian forces were often supported by extensive defensive fire from behind their lines. North Korean and the Chinese forces frequently knew where the Australian defensive fire would fall, having previously located the locations through patrol contacts. Artillery support was also an essential aid to Australian patrol commanders navigating their way through no man's land and identifying enemy positions.

\section{Patrols during the static war period}

The patrol war gave junior leaders the opportunity to use their own tactics of movement, with formations and use of weapons that were best suited to individual tasks and the abilities of the leaders and their platoons. Formations varied, depending on the platoon commander: single file, file, arrowhead, blob or box formation. Patrol leaders decided how many automatic weapons to take with them and how many they had to 
leave in their position for the defence of their defended localities. They decided where to place those weapons, what action the patrol would take on contact with the enemy, the use of grenades, and the use and layout of ambush formations. Patrol leaders also decided how to establish firm bases, from which they would frequently detach small reconnaissance or snatch groups to take prisoners from enemy lines.

Box formation was one popular patrol grouping, with men moving out spaced in a rough rectangular shape, with the commander in the centre. This allowed good control and communication within the patrol, aggressive immediate assault action on contact with the enemy and a ready-made, all-round ambush formation.

\section{1st Battalion, Royal Australian Regiment patrols: Hill 355}

A good example of how and why Australian troops patrolled, the intensity they experienced and the enemy tactics they encountered, is an operation undertaken by 1RAR on Hill 355 in October and November 1952.

Hill 355, which had been taken as part of Operation Commando, was considered to be divisional 'vital ground'. Not surprisingly, Chinese forces decided to recapture it from the defending UN unit. The enemy had detected that little patrolling was being done by the UN unit. Over a number of nights, the enemy crossed no man's land in the valley and was unhindered as it dug caves and tunnels big enough to shelter large numbers of troops from artillery fire around the base of Hill 355. Attacking troops infiltrated, without interception, across the valley into these caves before attacking the hill. When the attack started, UN artillery defensive fire, which might have caught enemy troops crossing the valley, was largely ineffective, as the enemy was already protected and on its objectives. Before the attack was defeated, the enemy captured the forward UN company position on the hill, and our battalion was sent to relieve the UN unit the next morning. This meant clearing and restoring the completely demolished forward company positions and starting an intensive patrol program to dominate no man's land.

The program immediately implemented by $1 R A R$ was to saturate no man's land with fighting patrols. Many platoons conducted two fighting patrols each night for around two weeks. The platoon commander would take half the platoon from last light to midnight, then the platoon sergeant 
would take the other half from midnight to dawn. The caves used by Chinese forces for their attack were destroyed, and minefields and barbed wire were restored. Although some contacts with enemy patrols occurred, no other Chinese raid or attack was mounted on Hill 355 for the duration of our time there. I think it is fair to say that this can be largely attributed to the fact that we dominated no man's land.

\section{Chinese defensive patrol tactics}

Chinese patrol tactics were similar to Australian defensive patrol tactics. Chinese patrols were well armed and reacted with aggression. There are numerous examples of the enemy rapidly reacting to our patrols, by artillery fire and despatching their own patrols, sometimes at platoon strength, to attack our firm bases, which we had set up before sending off recce or snatch groups. The enemy closely followed up and attacked our withdrawal from these firm bases.

Frequently Chinese forces would set up ambushes near entrances to (or even inside) our minefields in order to catch patrols that had relaxed and let their guard down after a night's operations. One tactic Chinese forces used to their advantage was heavily bombarding our positions around last light to prevent Australian patrols moving out-for it was frequently a race to get into no man's land first to establish ambush positions. Under cover of artillery, the enemy could get patrols into the valley after the artillery fire had lifted, then ambush our patrols coming out, at times catching us silhouetted against the skyline as we came down the ridges.

\section{Conclusion}

It is fair to conclude that minor tactics, the movement and operation at platoon level in Korea, were remarkable only because of their similarity to proven tactics of previous wars. This was largely because the weapons and technology in use had changed little. While the terrain was adapted to, the cold was perhaps the only new major influencing factor.

A major difference, for Australian troops at least, was the existence of an almost entirely well-trained force led by experienced or well-trained professionals at junior levels of leadership. Tried and tested tactics of the 
desert and jungles of the Second World War were mirrored in actions in 1950 and 1951, while conditions and operations of the First World War were evident from 1952 to 1953.

I would like to conclude with a quote about infantry in the Second World War. The words are from the Australian company commander Joe Gullett's book, Not as a Duty Only. On my return from Korea, he gave me a copy of his book with some areas marked. I quote his words, as I believe they epitomise the actions and the spirit of our rifle platoons in Korea:

An infantry battalion in being implies a state of mind-I am not sure it is not a state of grace. It involves a giving and a taking, a sharing of almost everything-comforts, possessions, trust and confidence. It implies doing a hundred different things togethermarching to the band, marching all night long, being hungry, thirsty, dirty, being near to but never quite mutinous. It involves the spirit to carry things through to the butt and bayonet and the determination that what we go for, we get and what we get, we hold. ${ }^{2}$

This was the spirit shown by Australian infantry platoons in Korea. 
This text is taken from In from the Cold: Reflections on Australia's Korean War, edited by John Blaxland, Michael Kelly and Liam Brewin Higgins, published 2020 by ANU Press, The Australian National University, Canberra, Australia. doi.org/10.22459/IFTC.2019.09 